\title{
ATIK KAĞIT KATKILI ÇIMENTO HARÇLARININ BAZI MEKANIK ÖZELLIKLERI
}

\author{
Ayşe KAÇAR ${ }^{*}$ \\ Süleyman Demirel Üniversitesi, Teknoloji Fakültesi İnşaat Mühendisliği Bölümü, Isparta, Türkiye
}

\begin{tabular}{|c|c|}
\hline Anahtar Kelimeler & Öz \\
\hline $\begin{array}{l}\text { Atık Kağıt, } \\
\text { Çimento harç, } \\
\text { Sürdürülebilirlik, }\end{array}$ & 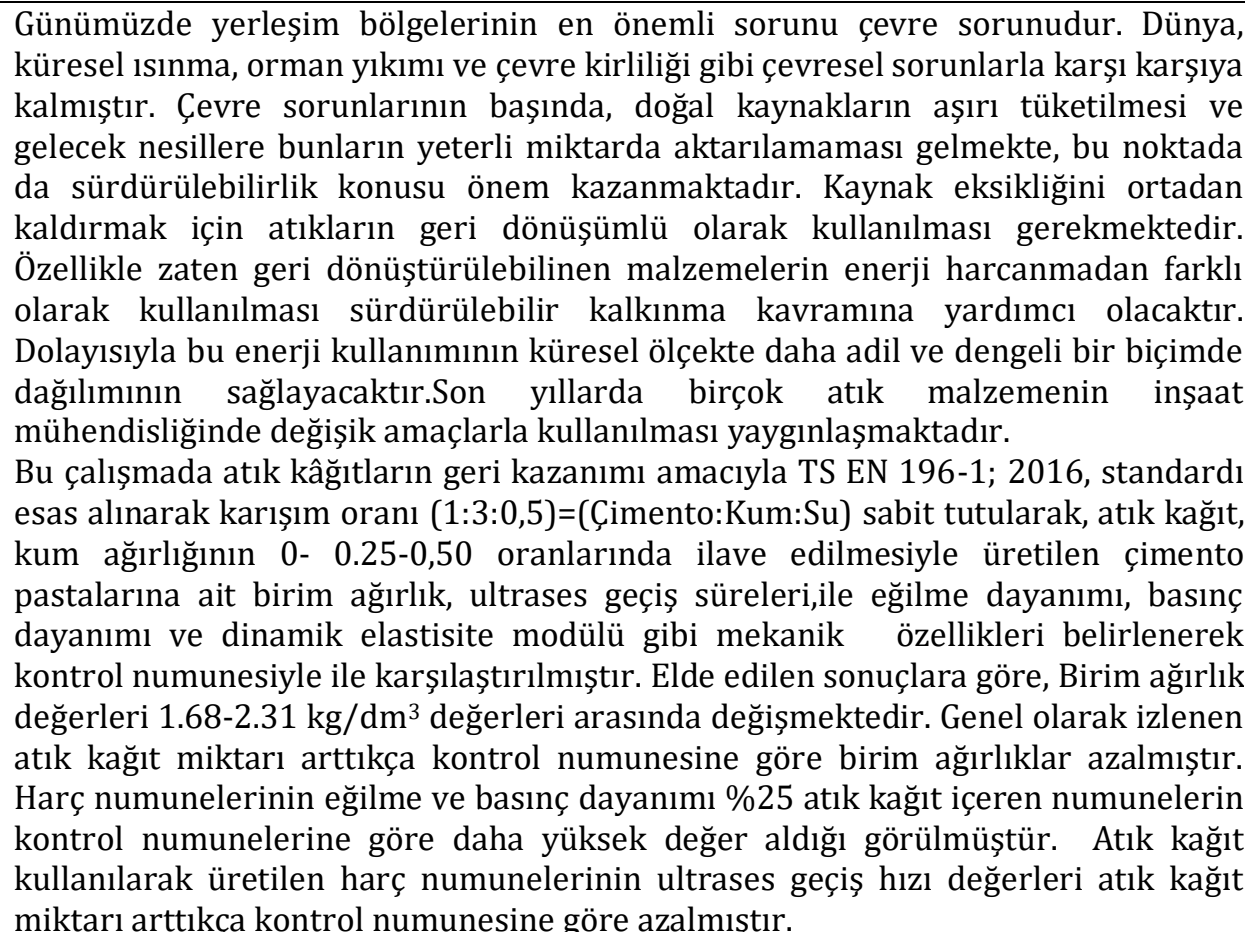 \\
\hline
\end{tabular}

\section{SOME MECHANICAL PROPERTIES OF WASTE PAPER ADDED CEMENT} MORTARS

\section{Keywords}

Waste Paper,

Cemen Mortar,

Sustainability,

\begin{abstract}
Nowadays, one of the most important problem of settlements is environmental problem. The world has to faced environmental problems such as global warming, forest destruction and environmental pollution. At the beginning of environmental problems, excessive consumption of natural resources and the inability to transfer them to future generations are coming, and sustainability is becoming more important in this point. In order to remove the resource incompleteness, it is necessary to use recycles of the waste. So this will ensure a more equitable and balanced distribution of energy use on a global scale. In recent years, it has become widespread that various waste materials are used for various purposes in civil engineering.

In this study, the cement mortars was produced with adding waste paper for recovery waste paper for this purpose of mix design was Based on the standard of TS EN 196-1,2016, keeping the mix ratio as(1:3:0,5)= (Cement:Sand:Water) and waste paper was added $0-0.25-0.50$, ratios of sand weight. The unit weight of of samples, ultrasound transition times, bending strength, pressure properties and dynamic modulus of elasticity were determined and compared with the control sample.
\end{abstract}

\footnotetext{
* ilgili yazar / Corresponding author: aysekacar@sdu.edu.tr, +90-246-211-1444
} 
According to the results obtained, unit weight values vary between $1.68-2.31 \mathrm{~kg} /$ $\mathrm{cm} 3$. As the amount of waste paper in general increases, the unit weights decrease according to the control sample. Mortar samples were found to have higher bending and compressive strength than the control samples of samples containing $25 \%$ waste paper. The ultrasound transit speed values of mortar samples produced using waste paper decreased as the amount of waste paper increased compared to the control sample.

\begin{tabular}{|c|c|}
\hline \multicolumn{2}{|l|}{ Alıntı / Cite } \\
\hline \multicolumn{2}{|c|}{$\begin{array}{l}\text { Kaçar, A.,(2017). Atık Kağıt Katkılı Çimento Harçlarını } \\
\text { Sciences and Design, 6(1), 1-6. }\end{array}$} \\
\hline \multicolumn{2}{|c|}{ Yazar Kimliği / Author ID (ORCID Number) } \\
\hline \multicolumn{2}{|l|}{ A. Kaçar, $0000-0002-1689-5967$} \\
\hline Başvuru Tarihi /Submission Date & 28.11.2017 \\
\hline Revizyon Tarihi / Revision Date & 12.12.2017 \\
\hline Kabul Tarihi / Accepted Date & 25.12 .2017 \\
\hline Yayım Tarihi / Published Date (Online) & 26.12.2017 \\
\hline
\end{tabular}

Günümüzde yerleşimlerin en önemli sorunlarından biri çevre sorunlarıdır. Dünya, küresel ısınma, orman yıkımı ve çevre kirliliği gibi çevresel sorunlarla karşı karşıya kalmıştır. Çevre sorunlarının başında, doğal kaynakların aşırı tüketilmesi ve gelecek nesillere bunların yeterli miktarda aktarılamaması gelmekte, bu noktada da sürdürülebilirlik konusu önem kazanmaktadır (Çetinkaya ve Ciravoğlu, 2016) .

Sürdürülebilirlik kavramı ilk olarak 1987 yılında Dünya Çevre ve Kalkınma Komisyonu'nun yayınladığı raporda ortaya çıkmıștır. Bu raporda sürdürülebilir kalkınma; "Bugünün ihtiyaçlarını, gelecek kuşakların da kendi ihtiyaçlarını karşılayabilme olanağından ödün vermeden karşllamaktır" şeklinde tanımlanmıştır (Harris, 2000).

Değişik türdeki gaz, sıvı ve katı atıkların kaçınılmaz olarak üretildiği kâğıt endüstrisi çevreyi kirletme dereceleri açısından sıralandığında altıncı sırada yer almaktadır. Kaynak eksikliğini ortadan kaldırmak için atıkların geri dönüşümlü olarak kullanılması gerekmektedir. Son yıllarda birçok atık malzemenin inşaat mühendisliğinde değişik amaçlarla kullanılması yaygınlaşmaktadır (Binici vd., 2013). Beton sektörünü sürdürülebilir kılmak için atıkların doğal kaynaklar yerine kullanılması güncel yaklaşımlardandır.

Geri dönüştürülebilinen malzemelerin farklı uygulama alanlarında enerji kullanımı olmadan yeniden kullanılması sürdürülebilir kalkınma yönünden istenen bir davranıştır. Dolayısıyla buy olla enerji kullanımının küresel ölçekte daha adil ve dengeli bir biçimde dağılımı sağlanacaktır.

Geri dönüştürülen atıkların \% 43'ünü kâğgtt, \% 27'sini plastik, \% 12'sini cam, \% 8'ini tekstil ürünleri, \% 4'ünü de metal oluşturur (Yetim 2014). AB'de üretilen yaklaşık 2,5 milyar ton atığın 1,150 milyon tonunu temel geri dönüştürülebilenler (kağıt ve karton, plastik, demir ve çelik, alüminyum, bakır ve nikel, değerli metaller, diğer metaller, cam, elektronik atıklar, inşaat ve yıkıntı atıkları) olușturmaktadır. Bu miktarın 680 milyon tonu geri dönüştürülmektedir. Ambalaj atıklarının geri dönüşümü alt atık türlerine (cam, plastik, metal, kağıt ve karton gibi) göre farklılık göstermektedir. En yüksek geri dönüșüm oranı kağıt ve kartonda en düşük oran ise plastikte yaşanmaktadır. Kâğıt geri dönüşümü uygulanabilirlik açısından en kolay olan maddedir. Kağıt ve ambalaj atıkları atık zincirinde büyük miktarda yer alırlar. $\mathrm{Bu}$ yüzden geri dönüșümleri çevreye büyük ölçüde fayda getirecektir.

Kâğıt, bitkisel liflerin hamur haline getirilip yapraklar halinde kurutulması ile elde edilen yarı sentetik bir maddedir. Kâğıt hammaddesi olarak günümüzde odun kullanilmakta ise de tarih boyunca bambu, pamuk, keten, kenevir, paçavra ve ipler yaygın olarak kullanılmıștır. Kâğıt üretiminde kullanılan hammaddelerin temel yapıtaşı ilk defa 19 yüzyılın ortalarında Amselme Payen tarafindan odundan saflaştırılabilinen selülozdur (Șekil 1.).

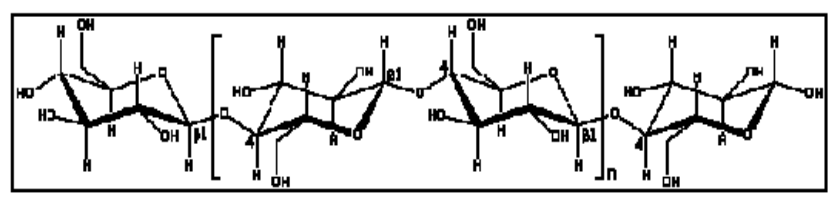

Şekil 1. Selülozun molekül yapısı (Konuklar 2011)

Kağıt hamuru ve kağıt üretiminde lifler ve kimyasal maddeler dişında büyük miktarda su ile buhar ve elektrik enerjisi kullanılmaktadır. Dolayısıyla kağıt hamuru ve kağıt üretiminde çevre ile ilgili en önemli hususlar, suya ve havaya yapılan salımlar ve enerji tüketimdir. Atıkların gün geçtikçe artan çevresel bir sorun olacağı tahmin edilmektedir (IPPC,2001).

Kağıt selülozik lif olarak zengin bir kaynak olarak çeşitli formlarda (gazete kağıdı,1. Kalite kağıt, saman kağıdı vb.) günümüz evsel atıklarının \%41 ini üretmektedir. (Akinwumi, vd., 2014 ).

Dünya'da kâğıt tüketiminin artmasına paralel olarak, evsel ve endüstriyel katı atıklarla birlikte atılan kâğıt miktarları da artmaktadır. Katı atıklar içindeki kâğııt miktarının artması ile birlikte kâğıt atıkları da dâhil, 
diğer atıkların da geri kazanılması ve daha az atık çlkaran teknolojilerin geliştirilmesi ve seçimi yönünde çalışmalara başlanmıştır. Değişik türdeki gaz, sıvı ve katı atıkların kaçınılmaz olarak üretildiği kâğıt endüstrisi çevreyi kirletme dereceleri açısından sıralandığında altıncı sırada yer almaktadır (Binici vd.,2013).

Bu çalışmada atık kâğıtların geri kazanımı amacıyla TS EN 196-1; 2016, standardı esas alınarak karıșım oranı $(1: 3: 0,5)=(C ̧$ imento:Kum:Su) sabit tutularak, atık kağıt, kum ağırlığının $0-0.25-0,50$ oranlarında ilave edilmesiyle üretilen çimento pastalarına ait birim ağırlık, ultrases geçiş süreleri,ile eğilme dayanımı, basınç dayanımı ve dinamik elastisite modülü gibi mekanik özellikleri belirlenerek kontrol numunesiyle ile karşılaştırılmıştır.

\section{Bilimsel Yazın Taraması}

Çalışmanın amacı sürdürülebilirlik kavramı açısında atık malzemelerin hammadde gereksinimini en aza indirgeyerek en az enerji tüketimi ilkesi ile inşaat mühendisliği uygulamalarında atıkların dâhil edilmesi ile üretilecek olan numunelerin kontrol numuneleri ile özelliklerinin karșılaștırılmasıdır. Bu kapsamda ilgili bilimsel yayınlar incelendiğinde sürdürülebilirlik kapsamında;

Akinwumi vd. (2014) çalışmasında ofis atık kâğıtlarının bazı fiziksel ve mekanik özelliklerini belirleyerek alternatif bir inşat malzemesi olarak kullanımını araştırmıştır. Özellikle Yüksek su emme özelliği nedeniyle diş duvarlar ve zemine yakın duvarlar için atık katkılı betonların kullanılmaması gerektiğini göstermiştir.

Binici vd. (2016) çalışmasında, polietilen bardaklardan çimentosuz harçların üretimi araștırmışlardır. Elde edilen harçların eğilme, basınç, tokluk, su emme ve aşınma özellikleri araştırarak eritilmiş PE katkılı harçların eğilme ve tokluk özellikleri geliştirdiğini göstermişlerdir.

Topçu vd.(2009) çalışmalarında atık lastik agregasını çimento harçlarına belirli oralarda ilave ederek, basınç ve eğilme dayanımları ve ultrases geçiş hızlarının kontrol harçlarına daha düşük çıktığın göstermişlerdir.

Binici vd. (2013) çalışmalarında, atık kâğıt ve mukavva esaslı malzemeleri uçucu kül ve barit ile kompozit bir yalıtım malzemesi üreterek Numunelerin ısı iletim katsayısı, ultra ses geçirgenlik katsayısı ve radyoaktif geçirgenlik özelliklerini belirlemişlerdir. Çalışma sonuçlarına göre tamamı kağıt hamurundan üretilen kompozitin ısı yalıtımı diğer numunelere göre daha iyi sonuç verirken çimentolu uçucu küllü kompozitin ses yalıtımı diğer numunelere göre daha iyi sonuç verdiğini göstermişlerdir.

Aciu, vd. (2014) Çalışmasında eklojik sıva harcı olarak kağıt katkılı harçlar üretmiştir. Dört fakı harç karışım oranına göre ürettiği harçlar üzerinde $\% 40$ oranında kağıt atık ilavesinin optimum olduğunu belirtmiștir. Kontrol serisine göre birim ağırlık bakımından daha hafif malzeme olduğunu da ayrıca belirtmiştir.

Yapılan çalışma sırasında fark edilmiştir ki literatürde harç üretiminde atık kağıt kullanımı neredeyse yoktur. $\mathrm{Bu}$ yüzden yapılan çalışma literatüre destek sağlayacaktır.

\section{Materyal ve Yöntem}

\subsection{Materyal}

Çalışmada, CEM I-42.5/R tipi Çimento kullanılmıștır. Harç karışımlarında birim ağırlı̆̆ $1.352 \mathrm{~kg} / \mathrm{dm}^{3}$, özgül ağırlığı ise 2.563 olan Standart Rilem kumu kullanılmıștır. Kullanılan atık kağıtların yoğunluğu $0,7 \mathrm{~kg} / \mathrm{dm}^{3}$ olup Isparta'da fotokopi merkezlerinde kullanılan 1.kalite hamur kağıt atıklarıdır (Şekil 1).

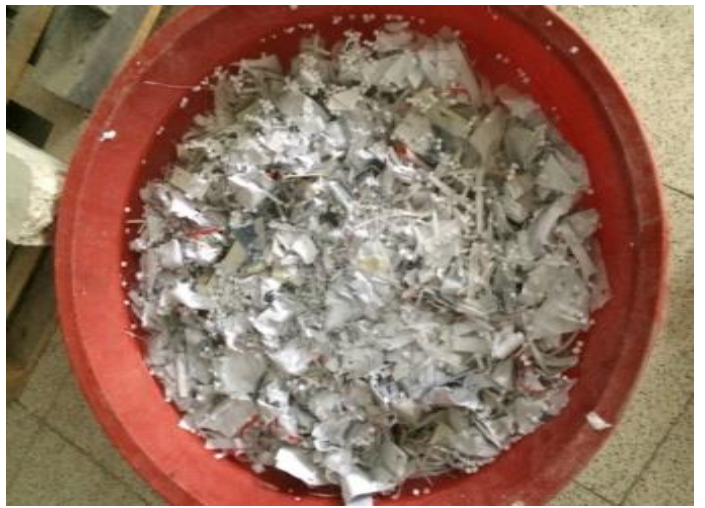

Şekil 1. Çalışmada kullanılan atık kâğıt

\section{2. Önerilen Yöntem}

Fotokopi merkezlerinde atık olarak alınan kâğıtlar küçük parçalara ayrılarak Şekil 3'de görüldüğü üzere liflerine ayrılıp homojen olarak karıșımın sağlanması amacıyla 48 saat su içerisinde bekletilmiștir.

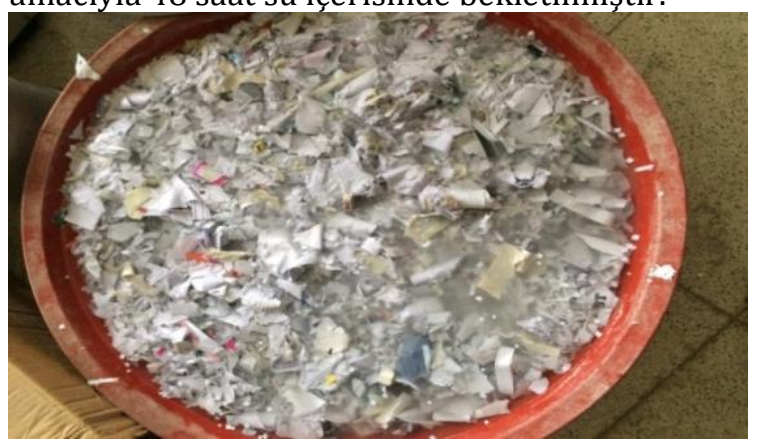

Şekil 3. Kâğıt hamuru için kâğıtların suda bekletilmesi

Bekletme aşamasının ardından kağıt hamuru elde etmek için su emdirilmiş olan kağıtlar çimento harç mikserinde Şekil 4'de görüldüğü gibi homojen hamur haline gelinceye kadar karıștırılmıştır. 


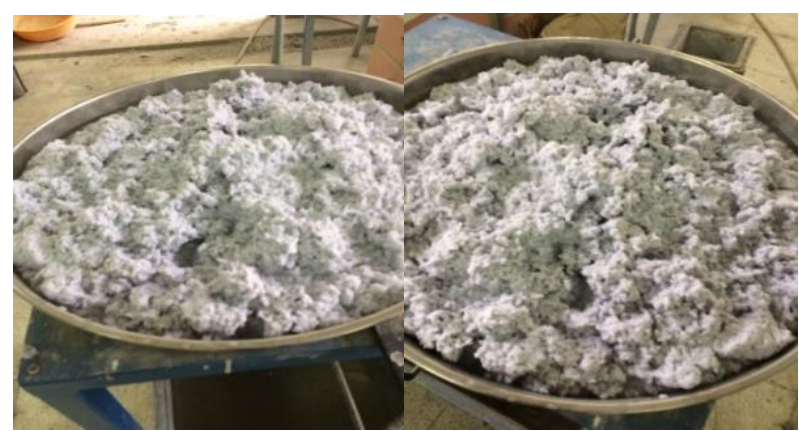

Şekil 4. Üretilen Kağıt Hamurları

Harçların Üretilmesi: TS EN 196-1'e uygun olarak üretilen 40x40x160 mm boyutlu harç numuneleri için karışım oranı 1:3:0.5, Çimento: Kum: Su olarak sabit tutulmuştur. (Şekil 5a-b-c). Su miktarı atık kâğıt hamuru su içerdiği için karşım boyunca işlenebilirliğe göre ayarlanmıştır. Harçlarda Çimento Yayılma Tablası kullanılarak, yayılma miktarları standart aralıklarda tutulmuştur. Serilerde değişkenlik kum hacimce \% 0-25-50 oranlarında azaltılıp yerine azaltılan oran kadar atık kâğıt ile değiștirilmesiyle $\mathrm{K}$, 25 ve 50 Kodlarında seriler üretilmiştir.

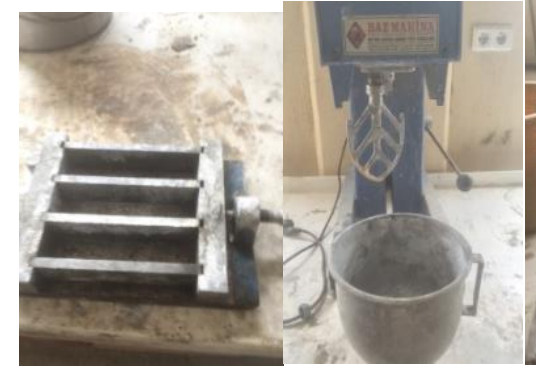

(a)

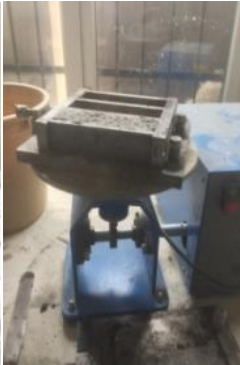

(c)
Şekil 5. Karıșımların hazırlanması ve sıkıștırılması

Üretilen harçlar 24 saat sonra kalıptan çıkarılmış, deney zamanı olan 28. Güne kadar $20 \pm 2{ }^{\circ} \mathrm{C}$ kirece doygun su içerisinde küre tabi tutulmuștur.

Harç numunelerinin birim ağırlıkları, ultrases geçiş süreleri, eğilme dayanımı yükleri ve basınç dayanımı yükleri Şekil 6 a,b,c'de görülen deney düzenekleri ile tespit edilmiştir. Numunelere ait dinamik elastisite modülü ise birim hacim ağırlık ve ultrases geçiş hızına bağlı olarak hesaplanmıștır.

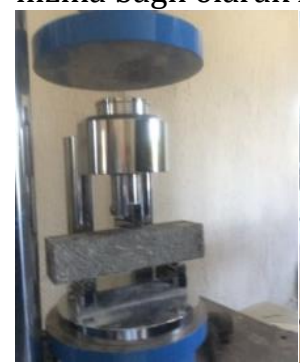

(a)

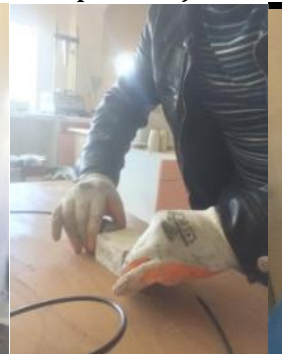

(b)

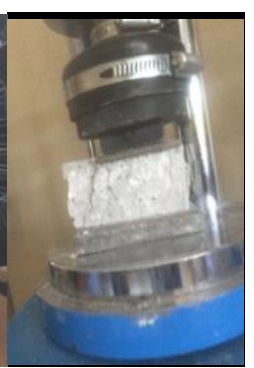

(c)
Şekil 6. Yapılan hasarlı ve hasarsız deneyler

Harç numuneleri üzerinde hasarsız deneylerden Birim Ağırlık ve Ultrases Geçiş Süresi deneyleri ilk olarak yapılmıştır.
Mekanik özelliklerin tespiti için hasarlı deneylerden basınç ve Eğilme Dayanımı deneyleri yapılmıştır. Basınç presinin kapasitesi $200 \mathrm{kN}$ olup, eğilme presinin kapasitesi de $50 \mathrm{kN}$ 'dur. $40 * 40 * 160 \mathrm{~mm}$ boyutlu prizma örnekler üzerinde eğilme ve sonrasında basınç deneyi yapılmış Eğilme dayanımının tespiti için Şekil 6a'da görüldügü gibi 3 noktadan yüklemeli deney düzeneği kullanılmış ve Eşitlik (1) kullanılarak eğilme dayanımları belirlenmiştir.

$$
\sigma=\frac{3 P L}{2 b h^{2}}
$$

P: Maksimum Yük, L: Yükleme açıklığı, b:Numune Kalınlığı, h: Numune yüksekliği

Basınç dayanımı deneyi için Şekil 6c'de verilen düzenek kullanılmıştır. Numunelerin alt ve üstüne aynı düşey eksen çizgisindeki mesafeye gelecek şekilde 40x40 mm plakalar yerleştirilmiştir. Bu halde basınç presi tablaları arasına yerleştirilen numunelere basınç yükü uygulanarak dayanım değerleri belirlenmiştir. Şekil 7. (a-b)’de örneklerin yüklemeden sonraki durumu görülmektedir.

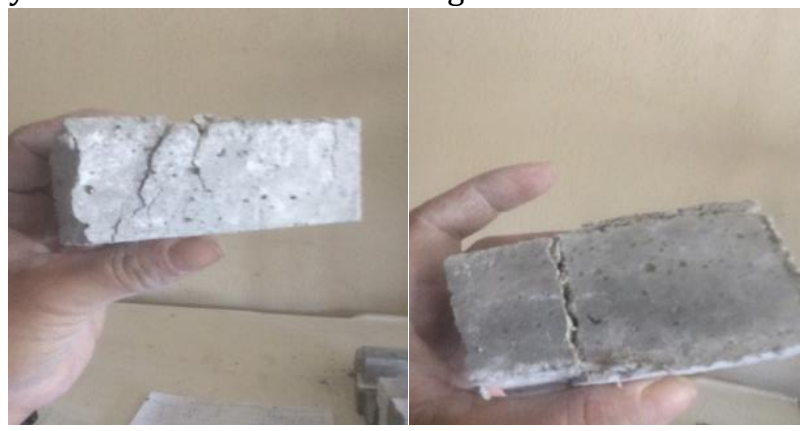

(a)

(b)

Şekil 7. Yapılan hasarlı deneyler

Numuneler üzerinde gerçekleştirilen ultrases geçiş hızı ve birim ağırlık deney verileri kullanılarak dinamik elastisite modülleri de așağıda verilen Eşitlik (2) kullanılarak bulunmuştur.

$$
E d=\frac{\Delta}{g} 10^{5} V^{2}
$$

$\Delta$ :Numune birim hacim Ağırlı̆̆ $\left(\mathrm{kg} / \mathrm{dm}^{3}\right)$, g:Yerçekim ivmesi (m/sn²) V:Ultrases hızı (Km/sn)

\section{Araştırma Bulguları}

\subsection{Deneysel Sonuçlar}

Yapılan hasarsız deneyler neticesinde Birim Ağırlık, Ultrases Geçiş Hızı ve Dinamik Elastisite Modülüne ait sonuçlar Şekil 8. ve Şekil 9'da verilmiştir. 


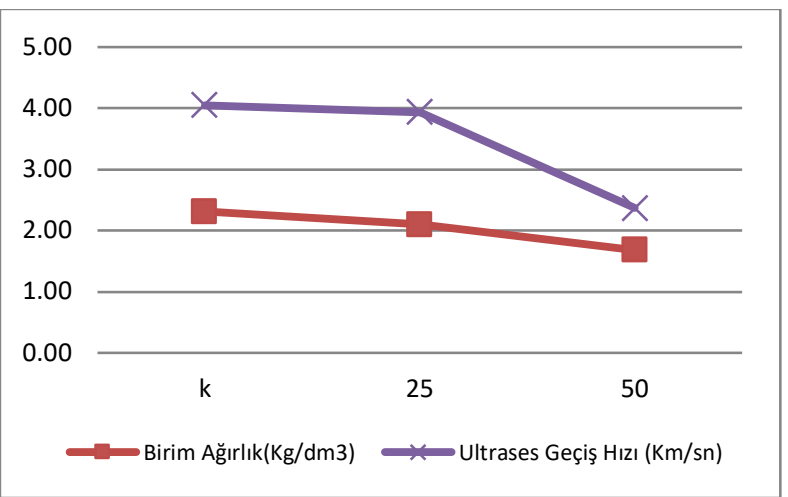

Şekil 8. Birim Ağırlık, Ultrases Geçiş Hızı sonuçları

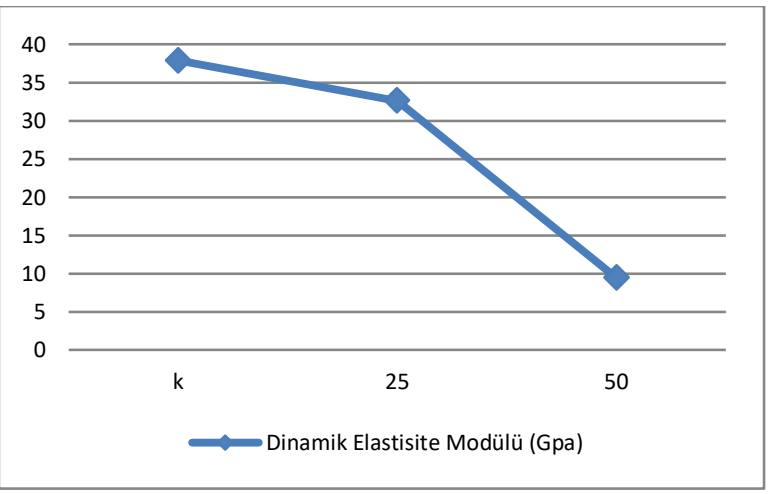

Şekil 9. Dinamik Elastisite Modülüne sonuçları

Harç içerisine ilave edilen atık kâğıt oranı arttıkça harçların birim ağırlık değerleri de azalmıştır. Harç veya beton içerisine ilave edilen atık kâğıtların topaklaşmaya sebep olması ve bunun sonucunda bileşenlerin hareket kabiliyetlerinin azalarak harç kıvamının azalması ve boşluklu kalması ile bu azalma açıklanabilir. Numunelerin ultrases geçiş süreleri deney neticesinden tespit edilerek hesaplanmıștır. Bir beton ortamında ölçülen sismik dalga hızları o ortamın doluluğu veya kompasitesi hakkında yeterli ve güvenilir bir fikir verir. Beton ortamında ses geçiş hızının yüksek olması ortamın dolu olduğunu gösterirken, düşük olması da bir miktar boşluk içerdiğinin göstergesidir (Erdoğan, 2003). Ses dalgaları boşlukta daha yavaş ilerlediklerinden daha düşük değerler elde edilmektedir. Atık kâğıt katkılı harçların da ses geçis hızları katkı oranı artmasıyla kontrol harcına göre daha düşük değerler aldığı Şekil 8.'de görülmüştür. Ultrases hızlarındaki azalmanın sebebi de birim hacimdeki ağırlık değerlerindeki azalma ile aynıdır.

Numunelerin Dinamik Elastisite (Ed) modülü değerleri. Kontrol harcına göre aynı şekilde atık oranının artmasıyla birlikte azalmıştır. Ultrases geçiş hızına ve birim ağırlıklarına bağlı olarak belirlenen dinamik elastisite modülündeki mantıklıdır.

Yapılan hasarlı deneyler neticesinde Basınç Dayanımı ve Eğilme Dayanımı değerlerine ait sonuçlar Şekil 10. ve Şekil11. 'da verilmiștir.

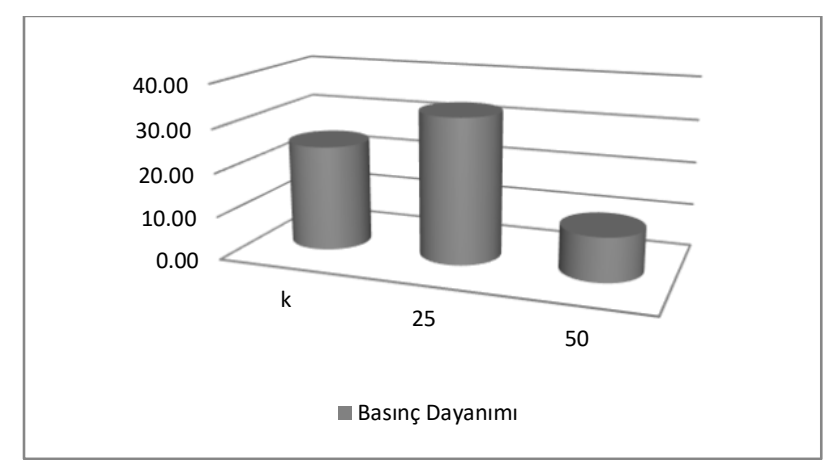

Şekil 10. Basınç Dayanımı Sonuçları

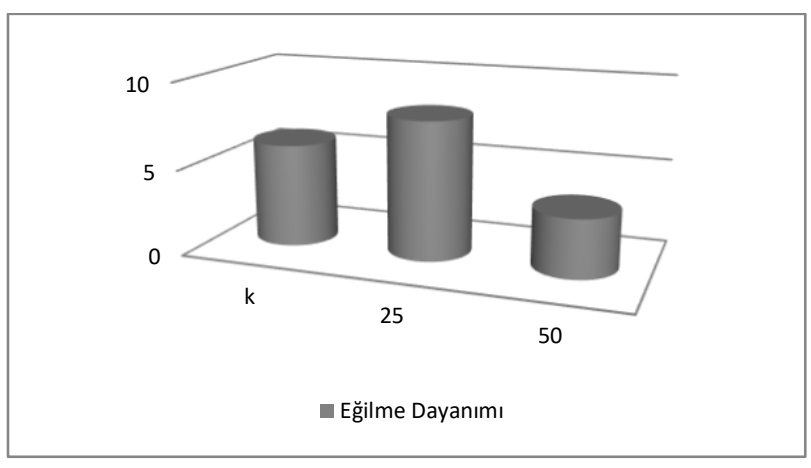

Şekil 11. Eğilme Dayanımı Sonuçları

Atık kağıt oranı ile basınç dayanımı ve Eğilme Dayanımı arasında değiş̧ken bir ilişki bulunmaktadır. \%25 atık kağıt katkılı harçların Hem Eğilme Dayanımları hem de Basınç Dayanım Değerlerinde kontrol harcına kıyaslan artış olmuş ancak atık oranı artıkça düşme başlamıştır. Bu düşme optimum atık kağıt oranını belirleme yönünde fikir edindirmektedir (Açıkgenç vd., 2012).

\section{Sonuç ve Tartışma}

Numunelere ait birim ağırlık değerleri 1.68-2.31 $\mathrm{kg} / \mathrm{dm}^{3}$ değerleri arasında değişmektedir. Genel olarak izlenen atık kağıt miktarı arttıkça kontrol numunesine göre birim ağırlıklar azalmıștır. $\mathrm{Bu}$ yönüyle hafif beton üretiminde katkı olarak atık kağıt kullanılabilir.

Eğilme ve basınç dayanımı \%25 atık kağıt içeren harçlarda kontrol harcına göre daha yüksek bulunmuştur. Ancak bu orandan \%50 oranına gelindiğinde bu artıș düșme ile sonuçlanmıștır. Belirli oranlarda atık kağıt kullanımı beton dayanımına katkı sağlayacaktır.

Atık kağıt kullanılarak üretilen harç numunelerinin ultrases geçiş hızı değerleri atık kağıt miktarı arttıkça kontrol numunesine göre azalmıştır. Ultrases dalganın hızı ile betonun yoğunluğu arasında belirli bir ilişki bulunmaktadır. Yoğunluğu az olan bir betonda, yani içerisinde daha çok boşluk bulunan bir betonda, Ultrases dalgasının betonun bir yüzeyinden diğerine ulaşabilme süresi daha uzundur. Bir başka 
deyişle, betonun içerisindeki boşluk miktarı arttıkça, Ultrases dalga hızı daha az olmaktadır.

- Çeşitli bitkisel lifler belirli oranlarda veya uçucu kül gibi katkılar ilave edilerek iyileștirmeler sağlanabilir.

- Estetik ve tasarım çok yönlülüğü için renkli dokulu kağıtlar denenebilir.

- Ayırma (topaklanma önleyici) ve yapıșma özelliklerini geliştirmek için kimyasal katkılar denenebilir.

- Değişik tip ve dayanımdaki çimentolar kullanılabilir.

\section{Çıkar Çatışması}

Yazarlar tarafından herhangi bir çıkar çatışması beyan edilmemiştir.

\section{Kaynaklar}

Çetinkaya Z, Ciravoğlu A., 2016. Sürdürülebilir Yerleşim Modellerinin Karşılaştırılması: Eko-Kent ve Yavaş Kent, İdealkent. Sayı 18,. ISSN: 13079905

Binici H.,, Kucukönder, A. Sevinç A. H., Eken, M., Tufenk N., 2013. Atık Kağıt Ve Mukavvaların Yalıtım Malzemesi ve Radyasyon Tutucu Materyal Olarak Uretiminde Kullanılması., C.U. Muh. Mim. Fak. Dergisi, 28(1), Haziran

Yetim A., 2014. Geri Dönüşüm Sektörünün Dünyadaki Genel Görünümü Ve Türkiye'deki Durumu. AR\&GE BÜLTEN,

Konuklar, M.2011. Kâğıt Eserlerin Korunmasında Yeni Yöntem Araştırılması. Doktora Tezi, Fen Bilimleri Enstitüsü, Ankara Üniversitesi

Avrupa Komisyonu, 2001. Entegre Kirlilik Önleme ve Kontrol (IPPC) Executive Summary - Pulp and Paper Kağıt Hamuru ve Kağıt Sanayiinde Kullanılabilecek En İyi Teknikler Hakkında Referans Belgesi, , Aralık.

Akinwumi, I. I. , Olatunbosun, O. M., Olofinnade, O. M., Awoyera, P.O. 2014. Structural Evaluation of Lightweight Concrete Produced Using Waste Newspaper and Office Paper, Civil and Environmental Research www.iiste.org ISSN 2224-5790 (Paper) ISSN 2225-0514 (Online) Vol.6, No.7,

Topçu İ.B., Demir A. 2009. Farklı Çimentolarla Üretilen Lastik Agregalı Harçların Bazı Özellikleri, Politeknik Dergisi Journal of Polytechnic Cilt:12 Sayl: 3 s. 201-206.

Erdoğan T.Y.,2003. Beton. ODTÜ Geliștirme Vakfı Yayn. ve İletişim Şti, 130-160, Ankara, Mayıs,

Açıkgenç M., Arazsu U. and Alyamaç K.E., 2012. Farklı karışım oranlarına sahip polipropilen lifli betonların dayanım ve durabilite özellikleri. SDU International Technologic Science, 4(3): 41-54,

Aciu, C., Ilutiu-Varvara, D.A., Cobirzan, N. \& Balog, A. 2014. "Recycling of paper waste in the composition of plastering mortars", Procedia Technology 12, 295-300.

Harris,J.M. 2000. Basic Principles of Sustainable Development. Global Development and Environment Institute Working Paper:00-04, Tufts University, USA. 